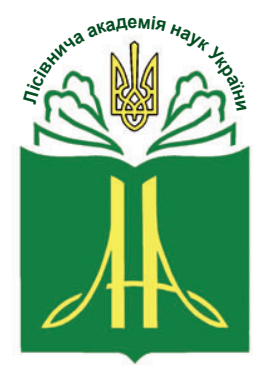

Forestry Academy of Sciences of Ukraine

Наукові праці Лісівничої академії наук України Proceedings of the Forestry Academy of Sciences of Ukraine

http://fasu.nltu.edu.ua

https://doi.org/10.15421/412002

Article received 2019.12.08

Article accepted 2020.06.04
ISSN 1991-606X print

ISSN 2616-5015 online

(a) $\triangle$ Correspondence author

Tetyana Prykladivska

prikladivska_tet@i.ua

General Chuprynka st., 103, Lviv, 79057, Ukraine

УДК 581.9:630*16

\title{
Види рослин і лишайників Кий-острова в Гербарії Національного лісотехнічного університету України (LWFU)
}

\author{
Т.Р. Прикладівська'
}

Кий-острів, щзо розташований в Онезькій затоці Білого моря (географічні координати 6400' $n$. ш., $37^{\circ} 53^{\prime}$ с. д.) - це виступ гранітної плити, яка залягає на незначній глибині і виходить на поверхню моря у вигляді скель. Геоморфологічні та кліматичні особливості острова, близькість до Північного полярного кола та Арктичної області, зумовили формування на ньому своєрідних природних комплексів, де переважають соснові ліси. Виконані в липні 1984 р. серії описів лісових біоченозів острова дали змогу встановити як основні типи цуих лісів (сосняк лишайниковый скальный, сосняк лишайниковый каменистый, сосняк лишайниковый багульникововересковый на вершинах сельг [Kucherov, Zverev, 2012; Rupestrian landscapes..., 2008; Rysin, 1975]), maк i відnовіdні їм типи асоиіацій (Pinetum cladinosum petraeum, Myrtillus-Calluna-Cladina-Typ, Pinetum uliginosi-vacciniosoledosum). Наведений перелік домінантних видів рослин і лишайників нижніх ярусів лісових біоценозів демонструє наявність у їх складі характерних представників бореальної та гіпоарктичної флори. Найбільша частина з них - ие класичні бореальні види: Andromeda polifolia L., Arctostaphylos uva-ursi (L.) Spreng., Chamaedaphne calyculata (L.) Moench, Ledum palustre L., Linnaea borealis L., Nardus stricta L. та інші. На другій позииіï знаходяться гіпоарктичні види, серед яких Betula nana L., Rubus arcticus L., Rubus chamaemorus L., Cornus suecica L. На поверхнях скель високу частку складають представники відділу Lichenотусота - характерні елементи північних та південних лишайникових тундр, а саме: Cladonia stellaris (Opiz) Pouzar \& Vězda, Cladonia sylvatica (L.) Hoffm., Cladonia rangiferina (L.) Weber ex F. H. Wigg., Cetraria islandica (L.) Ach., Peltigera aphthosa (L.) Willd.

Зібраний гербарний матеріал (45 зразків 16-ти таксонів) достатньою мірою відображає найбільи характерні риси біоти скельних сосняків Кий-острова та являє собою єдину колекцію видів з північної тайги європейської частини Росї в Гербарії Національного лісотехнічного університету Украӥни, який офіційно зареєстрований в міжнародних базах даних під акронімом LWFU.

Ключові слова: Кийський архіпелаг; Біле море; скельні сосняки; бореальна та гіпоарктична флора; гербарні зразки.

Вступ. Починаючи від середньовічних колекцій засушених рослин hortus siccus, які з часом трансформувались у відомі зараз гербарії, всі гербарні колекції, незалежно від періоду їх створення, завжди були цінним джерелом інформації про рослини. За сучасних умов, функціонуючи у складі музеїв, науково-дослідних установ і навчальних закладів, гербарії виконують важливу роль у нагро- мадженні, поглибленні і поширенні природничих знань.

Гербарій Національного лісотехнічного університету України заснований у 1945 році. Міжнародний акронім назви Гербарію відповідно до Index Herbariorum - LWFU (Herbaria of Ukraine..., 2011). Як і будь-який гербарій освітнього закладу, він насамперед виконує матеріально-дидактичне забезпе-

Прикладівська Тетяна Річардівна - кандидат сільськогосподарських наук, інженер 1-ої категорії відділу благоустрою та репродукції рослин Ботанічного саду. Національний лісотехнічний університет України, вул. генерала Чупринки, 103, м. Львів, 79057, Україна. Тел.: +38-032-237-88-20. E-mail: prikladivska_tet@i.ua ORCID: 0000-0002-0265-0651 
чення навчального процесу. Але, окрім навчальних, до складу гербарних фондів входять також наукові, особисті та історичні колекції. Серед особливо цінних експонатів Гербарію варто відзначити набори постійних мікропрепаратів кінця XIX ст., виготовлених у Відні, Празі, Львові, та унікальну збірку зразків деревини Євстахія Волощака, яка налічує 2808 взірців 602-х таксонів рослин з різних континентів Землі (Herbaria of Ukraine..., 2011; Soroka, Shovgan, Lukashchuk, 2003; Soroka, Osadchuk, Shovgan, 2017; Osadchuk, Soroka, Shovgan, Dolatovski, Kolodiy, 2017; Prykladivska, 2018; Soroka, Wozniak, 2018).

Незважаючи на те, що географічною спеціалізацією Гербарію є переважно Західні області України (Карпати, Волино-Поділля, Полісся), гербарні збори містять зразки з Одеської і Миколаївської областей, Криму, а також з Південної Свропи (Італії, Франції, Іспанії, Чорногорії, Болгарії). Важливу роль для Гербарію відіграють нові надходження, а серед них особливо ті, що представлені зразками, зібраними у віддалених і складно доступних географічних регіонах. Одним із таких останніх поповнень $є$ колекція видів біоти, зібраних автором на Кий-острові у Білому морі в липні 1984 року.

Об'скти та методика досліджень. Острів Кий, або Кий-острів, є частиною Кийського архіпелагу і розташований в Онезькій затоці Білого моря на відстані восьми кілометрів від витоку р. Онеги і в 15ти кілометрах від міста Онега Архангельської області. Географічні координати острова: $64^{\circ} 00^{\prime}$ п.ш., $37^{\circ} 53^{\prime}$ с.д. Його довжина становить дещо більше двох кілометрів, а ширина - від 100 до 800 метрів. Острів $\epsilon$ виступом гранітної плити, яка залягає на незначній глибині і виходить на поверхню моря у вигляді скель, що місцями сягають висоти більше двадцяти метрів (рис. 1).

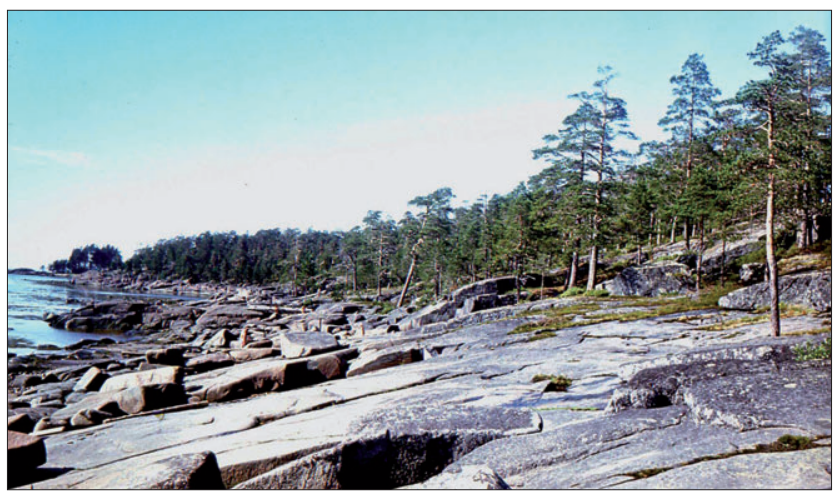

Рис. 1. Загальний вигляд західного берега Кий-острова, 1984 рік

Біле море за своїми фізико-географічними ознаками належить до арктичного басейну. Це глибоко врізана в материк океанська затока, але клімат морського узбережжя більш помірно-континентальний, ніж на прилеглих територіях, завдяки відсутності холодних течій і наявності повітряних потоків 3 океану, які несуть залишки тепла Мурманської течіiі. Біле море на зиму повністю не замерзає, але
Онезька затока вкрита льодом 185 днів на рік. Ця південна частина Білого моря більш мілководна i тепловодна, а температура води на поверхні поблизу берегів в середині липня може прогріватись навіть до $18-20^{\circ} \mathrm{C}$. Клімат власне Кий-острова континентальний з ознаками морського, що проявляється у відносно м'якій зимі (коли з настанням осені море, поступово охолоджуючись, віддає тепло суходолу) та досить високому рівні вологості повітря.

Дуже сильно впливають на берегову смугу припливи і відпливи. Двічі на день води Білого моря наступають на берег, місцями наближаючись до самого лісу, і двічі на день відплив оголює пісок і вкриті водоростями тисячі гранітних валунів, що лежать у морі поблизу узбережжя (рис. 2). Різниця між «малою» і «повною» водою біля берега може сягати 2,7 м. Близькість Північного полярного кола і Арктичної області нагадують про себе як вкрапленими типовими північними ландшафтами, так і характерними видами представників біоти. Завдяки вражаючим природним краєвидам та унікальній культурній спадщині, Кий-острів поправу вважають перлиною серед інших островів Білого моря.

У 1656 р. на острові за ініціативи патріарха Никона було розпочато будівництво Хресного монастиря, який упродовж кількох століть, поряд із Coловецьким монастирем, був потужним релігійним i просвітницьким центром Біломор'я. Ансамбль монастиря, створений ще за часів патріарха Никона, зберігся і до наших днів, щоправда із значними втратами. Цю унікальну пам'ятку архітектури i досі вважають однією із найцікавіших і найцінніших атракцій Півночі Росії.

Працюючи упродовж 1982-1986 рр. асистентом кафедри лісівництва Львівського лісотехнічного інституту, автор здійснила за цей період кілька поїздок на північ європейської частини колишнього СРСР для ознайомлення $з$ типологією, рубками і процесами відновленням лісів цього регіону, оскільки такі питання займали вагому частку в навчальних програмах дисциплін «Лісознавство» та «Лісівництво». Саме тому, коли під час однієї із таких подорожей у липні 1984 р. випала унікальна нагода побувати на Кий-острові, ми використали цей шанс для обстеження, насамперед, лісових ценозів, а вже принагідно і фрагментів інших, суміжних 3 ними, територій.

На жаль, за час нетривалого перебування на острові, довелось обмежитись тільки серією маршрутних обстежень, у процесі яких здійснювали фотознімання; окомірну таксацію деревостану, підросту і підліску; стислий опис нижніх ярусів біоценозу; а також збір деяких найпоширеніших видів лишайників і рослин для гербаризації та камерального уточнення їх таксономічної приналежності.

Маршрути обстежень прокладали зигзагоподібно. Основним напрямком руху обрали довгу сторону острова, яка приблизно орієнтована у напрямку південь-північ, а поперечні пересування здійснювали діагонально між західним і східним берегами. Тобто початок маршруту був на південно-західній 
точці острова, а далі рухались за схемою: на північний схід до берега, потім на північний захід до берега і так далі - аж до крайньої північної точки, звідки здійснювали рух аналогічно у зворотному напрямку на південь, але вже іншими ділянками, які не дублювали попередні. У такий спосіб залісену територію острова вдалось обстежити майже повністю. Під час збору гербарних зразків першочергову увагу звертали на типові північні види.

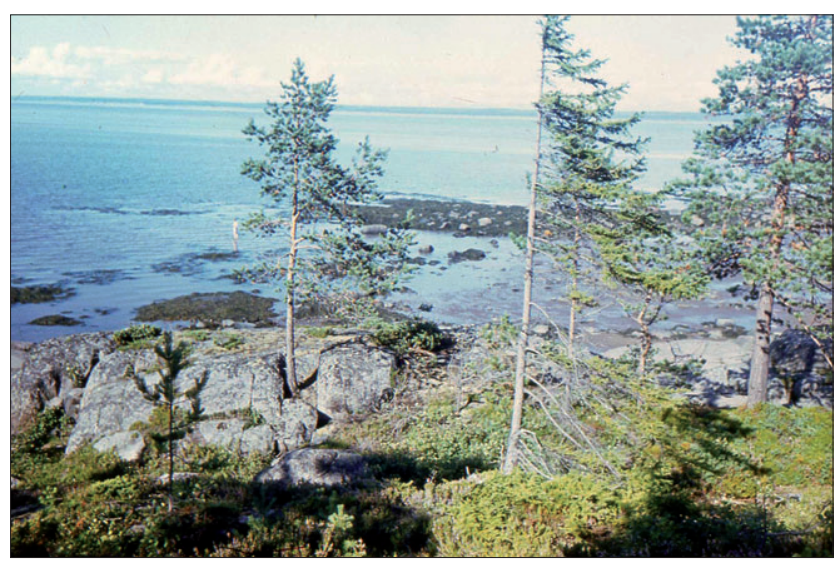

Рис. 2. Фрагмент східного берега Кий-острова під час відпливу, 1984 рік

Рослинне вкриття антропогенно змінених ландшафтів, таких як території монастиря і бази відпочинку, зони давньої митниці, лісової контори і порту не аналізували, оскільки ще від часів перших поселенців, коли спочатку монахи, а потім і прочани почали привозити на острів 3 материка грунт та культурні рослини, процес збільшення чисельності занесених видів тривав сотнями років і тому адвентивна флора, яка тут зосереджена, заслуговує на те, щоб бути об'єктом окремого дослідження.

Отриманий польовий матеріал упродовж наступних кількох днів попередньо опрацьовували вже за межами острова, в містах Онега та Архангельськ. Складено перелік домінантних видів лісових і суміжних $з$ ними ценозів. Допомогу у визначенні низки типових північних таксонів надала кандидат сільськогосподарських наук, доцент Архангельського лісотехнічного інституту Усова Діана Олексіївна.

У 2018 р. всі польові нотатки та збори остаточно доопрацьовано і передано до Гербарію Національного лісотехнічного університету України (LWFU). Кількість загербаризованих зразків налічує 16 таксонів, кількість листів гербарію - 45 одиниць. Окрім гербарних зразків, колекцію доповнено пояснювальною запискою, переліками домінантних і зібраних таксонів, оцифрованими фотографіями, виконаними під час перебування на Кий-острові, а також сканованими зразками гербарію.

Результати та обговорення. За ботанікогеографічним районуванням Кий-острів належить до Кольсько-Печорської підпровінції ПівнічноЄвропейської тайгової провінції Євразійської тайгової області (Vegetation of European part..., 1980), а за флористичним районуванням - до СхідноЄвропейської провінції Євросибірської підобласті Циркумбореальної області Бореального підцарства (National Atlas..., 2020).

Панівним типом рослинності Кий-остова є ліси, а саме, скельні сосняки, які ростуть на виходах кристалічних скельних порід (сельгах) по всій території середньої і південної тайги Східної Фенноскандії.

Ліси займають близько три чверті площі острова і представляють собою чисті різновікові одноярусні деревостани Pinus sylvestris L. V-V б бонітетів, віком 100-400 (500) років, 3 повнотою 0,1-0,4. Максимальні розміри дерев сягають висот 15-17 м і діаметрів 30-34 см. Трапляються поодинокі екземпляри Betula pubescens Ehrh. та Picea $\times$ fennica (Regel) Kom. (перехідні форми між Picea abies (L.) H. Karst. та Picea obovata Ledeb.). Склад підросту - 10C, piзновіковий, нерівномірний, фрагментами до 0,5-0,8 тис. шт./га. Підлісок відсутній або представлений поодинокими екземплярами Juniperus communis var. saxatilis Pall. (=J. sibirica Burgsd.), Betula nana L. та Sorbus aucuparia L. У нижніх ярусах трав'яна рослинність майже повністю відсутня, чагарнички ростуть куртинами, а лишайники на значних ділянках утворюють щільне суцільне вкриття. Окрім того, в пониженнях нанорельєфу, на незначних ділянках у «кишенях» сельг, як результат застою вологи, формуються так звані «скельні ванни», по краю яких виступають фрагменти болотної рослинності, з характерним домінуванням під наметом деревостану чагарників-гігрофітів.

Під час маршрутних обстежень лісових біоценозів особливу увагу звертали на склад і чисельність представників чагарничково-трав'яно-мохового та лишайникового вкриття. Нижче наводимо перелік найпоширеніших видів біоти нижніх ярусів соснових ценозів Кий-острова. Зірочками відзначено гербаризовані таксони. Латинські назви видів подано за двома джерелами: «Мусо Bank Database» (лишайники) та «The Plant List» (рослини).

\section{Fungi}

Lichenomycota: Cetraria islandica (L.) Ach.*, Cladonia stellaris (Opiz) Pouzar \& Vězda (=Cladonia alpestris (L.) Rabenh.)*, Cladonia rangiferina (L.) Weber ex F.H. Wigg.*, Cladonia sylvatica (L.) Hoffm.*, Peltigera aphthosa (L.) Willd.*

\section{Plantae}

Bryophyta: Dicranum undulatum Schrad. ex Brid., Hylocomium splendens (Hedw.) Schimp., Pleurozium schreberi (Willd. ex Brid.) Mitt., Polytrichum commune Hedw., Ptilium crista-castrensis (Hedw.) De Not., Sphagnum sp.

Equisetophyta: Equisetum sylvaticum L.

Polypodiophyta: Dryopteris carthusiana (Vill.) H. P. Fuchs, Gymnocarpium dryopteris (L.) Newman, Polypodium vulgare L.

Magnoliophyta: Allium lineare L.*, Andromeda polifolia L.*, Antennaria dioica (L.) Gaertn., Arcto- 
staphylos uva-ursi (L.) Spreng.*, Betula nana L.*, Calluna vulgaris (L.)Hull, Campanula glomerata L., Campanula patula L., Carum carvi L., Chamaedaphne calyculata (L.) Moench*, Comarum palustre L., Cornus suecica L.*, Dactylorhiza maculata (L.) Soó, Dianthus acicularis Fisch. ex Ledeb.*, Empetrum nigrum L.*, Epilobium angustifolium L., Eriophorum sp., Filipendula ulmaria (L.) Maxim., Galium boreale L., Juncus sp., Ledum palustre L., Leucanthemum vulgare (Vall.) Lam., Linnaea borealis L.*, Maianthemum bifolium (L.) F.W. Schmidt, Nardus stricta L., Oxalis acetosella L., Potentilla argentea L., Rubus arcticus L.*, Rubus chamaemorus L.*, Sedum acre L., Sedum maximum (L.) Suter, Trifolium aureum Pollich, Vaccinium myrtillus L., Vaccinium oxycoccos L., Vaccinium uliginosum L., Vaccinium vitis-idaea L.

За результатами обстеження, більшість лісових ценозів Кий-острова відповідає таким типам північно-тайгових скельних сосняків: «сосняк лишайниковый каменистый», «сосняк вороничный каменистый», «сосняк лишайниковый скальный», «сосняк воронично-лишайниковый». Аналіз наведених у літературі геоботанічних описів таких сосняків дає підставу прирівняти їх до наступних типів асоціацій: Pinetum cladinosum petraeum, Pinetum empetrosum petraeum (Rysin, 1975), Cladino-Pinetum subass. polytrichetosum communis, Empetro-CladinoPinetum (Kucherov \& Zverev, 2012).

Вони характеризуються доволі своєрідним поєднанням видів у нижніх ярусах, де поряд із лишайниками (рис. 3) і мезоксерофітами ростуть типові болотні види. Найбільшою рясністю відзначаються представники родів Cladonia та Cetraria і низка рослин - Empetrum nigrum, Arctostaphylos uva-ursi, Vaccinium vitis-idaea, Calluna vulgaris, Vaccinium myrtillus. Поряд 3 ними, але менш чисельно, ростуть Ledum palustre, Vaccinium uliginosum, Andromeda polifolia, Equisetum sylvaticum, Pleurozium schreberi, Polytrichum commune, Hylocomium splendens.

На півночі Фінляндії скельні сосняки описані як Myrtillus-Calluna-Cladina-Typ, Calluna-Cladina та Empetrum-Cladina-nodae, а в північній Швеції - як Pinus sylvestris-Calluna vulgaris-Empetrum spp.-typ (Rupestrian landscapes..., 2008).

Заболочені фрагменти соснового лісу, іноді навіть 3 невеличкими дзеркалами водної поверхні, можна прирівняти до такого типу як «сосняк лишайниковый багульниково-вересковый на вершинах сельг» (Rupestrian landscapes..., 2008), та, 3 різною мірою наближеності, до типів «сосняк голубично-багульниковый» i «сосняк сфагновобагульниковый» 3 групи асоціацій «сосняки багульниковые» - Pinetum uliginosi-vacciniosoledosum, Pinetum sphagnoso-ledosum (Rysin, 1975). Деревостани цих асоціацій відзначаються мінімальними показниками бонітетів, зімкнутості і висоти. Чагарниково-трав'яно-мохове вкриття дуже густе, іноді суцільне, з домінуванням Ledum palustre i значною участю Vaccinium uliginosum, Vaccinium oxycoccos, Eriophorum sp., Cornus suecica, Ru- bus chamaemorus, Polytrichum commune, Comarum palustre.

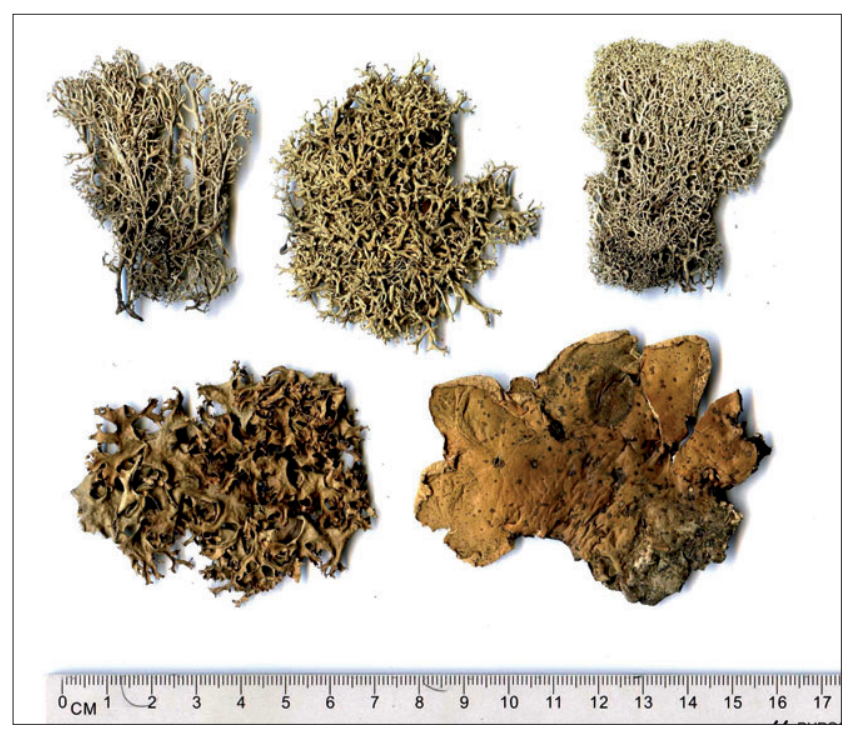

Рис. 3. Домінантні види лишайників Кий-острова. У верхньому ряду зліва направо: Cladonia sylvatica (L.) Hoffm., Cladonia rangiferina (L.) Weber ex F. H. Wigg., Cladonia stellaris (Opiz) Pouzar \& Vězda; у нижньому ряду ліворуч - Cetraria islandica (L.) Ach., праворуч Peltigera aphthosa (L.) Willd.

Надмірне зволоження таких екотопів одночасно поєднується 3 фізіологічною сухістю грунту, що $€$ результатом короткого вегетаційного періоду і незначною глибиною розповсюдження біологічно ефективних температур (Vinogradov, 1964). Характерною ознакою цих холодних грунтів $є$ рослинипсихрофіти, серед яких домінують Andromeda polifolia, Chamaedaphne calyculata, Arctostaphylos uva-ursi.

Аналізуючи географічно-зональну приналежність перерахованих у переліку видів, варто відзначити вагому частку у його складі рослин 3 широкими циркумполярними ареалами і таких груп рослинності, як бореальна та гіпоарктична. Найбільша частина - це класичні представники бореальної флори: Andromeda polifolia, Arctostaphylos uva-ursi, Calluna vulgaris, Chamaedaphne calyculata, Ledum palustre, Linnea borealis, Vaccinium oxycoccos, Vaccinium myrtillus, Vaccinium vitis-idaea та інші. На другій позиції знаходяться гіпоарктичні види (рис. 4). Серед них, насамперед, потрібно відзначити Rubus chamaemorus iз широким циркумполярним ареалом, а також такі види, як Betula nana, Rubus arcticus i Cornus suecica 3 амфіатлантичними ареалами. Betula nana та Rubus arcticus належать до домінантів усієї тундрової зони, а дерен шведський - Cornus suecica (=Chamaepericlymenum suecicum (L.) Asch. \& Graebn.) занесений до Червоної книги Східної Фенноскандії (Status: 3 - Rare. In «Red Data Book of East Fennoscandia»), оскільки поширений переважно в арктичній та субарктичній зонах, не властивий для континентальної частини ні Північної Америки, ні Азії та є досить не- 
типовим для оліготрофних низькоповнотних сосняків північної частини тайгової зони Європи. Проте у зволожених екотопах Кий-острова Cornus suecica формує фрагменти суцільного вкриття на площі від кількох до кільканадцяти квадратних метрів, що надає цим сосновим біоценозам особливої неповторності.

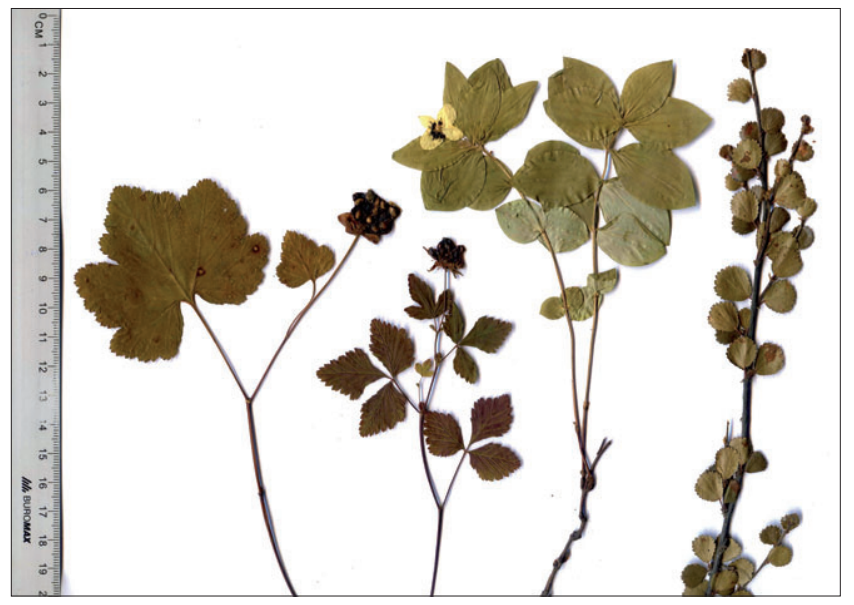

Рис. 4. Рослини Кий-острова, характерні представники гіпоарктичної флори.

Зліва направо: морошка (Rubus chamaemorus L.), малина арктична (Rubus arcticus L.), дерен шведський (Cornus suecica L.), береза карликова (Betula nana L.)

У складі деревної рослинності острова присутні також сибірські тайгові елементи, серед яких Juniperus sibirica та гібридні форми Picea obovata. Ну i звичайно ж, як домінанти цих лишайникових сосняків, на значних поверхнях скель, як відкритих ландшафтів, так і під наметом лісу, виступають найхарактерніші елементи північних та південних лишайникових тундр - представники відділу Lichenomycota, а, саме, види 3 родів Cladonia, Cetraria та Peltigera.

Висновки. Зібраний і опрацьований гербарний матеріал достатньою мірою відображає найхарактерніші риси біоти скельних сосняків Кий-острова. У Гербарії НЛТУ України він є єдиною колекцією видів 3 північної тайги європейської частини Росії і тому, незважаючи на незначну чисельність поданих зразків, може вважатись одним із непересічних надбань Гербарію.

Аналізуючи результати описів скельних сосняків Кий-острова та опрацьовані на їх основі гербарні збори, потрібно зазначити, що унікальна вразлива природа північної Свропи потребує не лише системних комплексних наукових досліджень із залученням фахівців різного профілю, але й активної популяризації вже набутих знань. Нагромадження відповідного фактичного матеріалу у музейних та гербарних колекціях сприятиме цьому якнайкраще, особливо в Україні, де можливості участі науковців у виконанні натурних обстежень будь-яких північних територій на цей час досить обмежені.

Передані до Гербарію Національного лісотехнічного університету України (LWFU) гербарні зразки 3 Кий-острова є цінним матеріалом для використання у дослідній та дидактичній роботі широкого кола зацікавлених осіб як $з$ навчальних закладів, так і з наукових установ. Завдяки сучасним інтернет-технологіям, виконане сканування гербарних зразків у найближчій перспективі надасть додаткові можливості дистанційного доступу до них в «online»-режимі на сайті Гербарію (http://herbarium. nltu.edu.ua), що не тільки створить додаткові зручності, але й необмежено розширить коло потенційних користувачів.

\section{References}

Aleksandrova, V.D. (1977). Geobotany zones of Arctic and Antarctic regions. Leningrad: Science (in Russian).

Flora of European part of USSR. (1974-1994). 1-7. Leningrad-Sankt-Petersburg: Science (in Russian).

Herbaria of Ukraine. Index Herbariorum Ucrainicum. (2011). Kyiv: Alterpres (in Ukrainian).

Kucherov, I., Zverev, A. (2012). Scots pine-lichen forests in the middle and northern taiga of European Russia. Tomsk State University Journal of Biology, 3 (19), 46-80. https://doi.org/10.17223/19988591/19/4 (in Russian).

Minyaev, N.A. (1969). Hypoarctic (arctic-boreal) elements in flora of north-west European part of USSR. In Ranges of plants of flora of USSR, 2, (pp. 34-47). Leningrad: Leningrad University (in Russian).

MycoBankDatabase. (2020). Available online: http:// www.mycobank.org/quicksearch.aspx. [Accessed 20.04.2020].

National Atlas of Russian Federation. (2020). Available online: http://национальныйатлас.pф/cd2/328-330/ 328-330.html. [Accessed 20.04.2020].

Osadchuk, L., Soroka M., Shovgan A., Dolatovski, J., \& Kolodiy, T. (2017). The collection of wood samples gathered by Yevstakhiy Voloshchak (1835-1918). To the 100th anniversary of the death of an outstanding scientist. Proceedings of the Forestry Academy of Sciences of Ukraine, 15, 163-179. https://doi.org/10.15421/411719 (in Ukrainian).

Pavalake, I.I. (1976). South border of distribution of arctic and arctic-alpine plants at European territory of USSR. In Ranges of plants of flora of USSR, 3, (pp. 144-162). Leningrad: Leningrad University (in Russian).

The Plant List. A working list of all plant species. (2020). Available online: http://wwwtheplantlist.org/ tpl1/record/kew [Accessed 20.04.2020].

Prykladivska, T. (2018). Plants specimens from the Crimea Mountains in the Herbarium of Ukrainian National Forestry University (LWFU). Visnyk of the Lviv University. Series Biology, 78, 126-130. http://dx.doi.org/10.30970/vlubs.2018.78.24 Ukrainian). 
Rupestrian landscapes of the White Sea Karelian Coast: natural characteristics, economic utilization, conservation (2008). Petrozavodsk: Karelian Research Centre of RAS (in Russian). http://www. krc.karelia.ru/publ.php?id=4415\&plang=e

Rysin, L. P. (1975). Pine forests of European part of USSR. Moscow: Science (in Russian).

Sokolov, S. J., \& Svyazeva, O. A. (1965). Geography of arbor plants of USSR. Moscow-Leningrad: Science (in Russian).

Soroka M., Shovgan A., \& Lukashchuk H. (2003). Historical herbarium and anatomic collections at the botany department of Ukrainian State Forestry University. Visnyk of the Lugansk State Pedagogical University, 11 (67), 129-132 (in Ukrainian).

Soroka M., Osadchuk L., \& Shovgan A. (2017). The Lviv collection of wood samples gathered by Yevstachiy Voloshchak (1835-1918). The Polish Dendrology Society Yearbook, 65, 35-45. http://www. ptd.pl/ptd/wp-content/download/wydawnictwaPTD/ rocznik65/4_Lwowska_kolekcja.

Soroka M., \& Wozniak A. (2018). Historical collections of Professor Władysław Tyniecki in the Herbarium of the National Forestry University of Ukraine (LWFU) Visnyk of the Lviv University. Series Biology, 78, 182186. http://dx.doi.org/10.30970/vlubs.2018.78.36 (in Ukrainian).

Vegetation of European part of USSR (1980). Leningrad: Science (in Russian).

Vinogradov, B.V. (1964). Use the plant indicators for the study of nature resources. Moscow: Higher school (in Russian).

\section{Виды растений и лишайников Кий-острова в Гербарии Национального лесотехнического университета Украины (LWFU)}

\section{Т.Р. Прикладовская}

Кий-остров, расположенный в Онежском заливе Белого моря (географические координаты $64^{\circ} 00^{\prime}$ с. ш., $37^{\circ} 53^{\prime}$ в. д.), представляет собой выступ гранитной плиты, которая залегает на незначительной глубине и выходит на поверхность моря в виде скал. Геоморфологические и климатические особенности острова, а также близость Полярного круга и Арктической области обусловили формирование на нем своеобразных природных комплексов, преобладающими среди которых являются леса.

Прикладовская Татьяна Ричардовна - кандидат сельскохозяйственных наук, инженер 1-й категории отдела благоустройства и репродукции растений Ботанического сада. Национальный лесотехнический университет Украины, ул. генерала Чупринки, 103, г. Львов, 79057, Украина. Тел.: +38-032-237-88-20, E-mail: prikladivska_tet@i.ua ORCID: 0000-0002-0265-0651
Выполненные в июле 1984 г. серии описаний лесных биоценозов Кий-острова позволили определить как основные типы этих лесов (сосняк лишайниковый скальный, сосняк лишайниковый каменистый, сосняк лишайниковый багульникововересковый на вершинах сельг, сосняк вороничный каменистый, сосняк воронично-лишайниковый), так и соответствующие им типы ассоциаций (Pinetum cladinosum petraeum, Myrtillus-CallunaCladina-Typ, Pinetum empetrosum petraeum, Cladino-Pinetum subass. polytrichetosum communis, Empetro-Cladino-Pinetum). Они характеризуются своеобразным сочетанием видов нижних ярусов, где рядом с лишайниками (Cladonia sp., Cetraria sp.) и мезоксерофитами (Arctostaphylos uva-ursi (L.) Spreng., Antennaria dioica (L.) Gaertn.,) pacтут типичные болотные виды (Empetrum nigrum L., Ledum palustre L., Vaccinium uliginosum L., Andromeda polifolia L.).

Заболоченные фрагменты сосновых лесов, иногда с небольшими зеркалами водных поверхностей, представлены такими типами леса, как сосняк голубично-багульниковый и сосняк сфагновобагульниковый, что соответствует типам ассоциаций Pinetum uliginosi-vaccinioso-ledosum и Pinetum sphagnoso-ledosum. Такие древостои отличаются минимальными показателями бонитетов, сомкнутости и высоты, а в их кустарниково-травяномоховом покрове преобладают в основном такие виды, как Ledum palustre, Vaccinium uliginosum, Vaccinium oxycoccos L., Eriophorum sp., Cornus suecica L., Rubus chamaemorus L., Polytrichum commune Hedw., Comarum palustre L.

Приведенный перечень доминантных растений и лишайников нижних ярусов лесных биоценозов острова демонстрирует наличие в их составе характерных представителей бореальной и гипоарктической флоры. Наибольшее их количество это классические бореальные виды: Andromeda polifolia, Arctostaphylos uva-ursi, Chamaedaphne calyculata (L.) Moench, Ledum palustre, Linnaea borealis L., Nardus stricta L. и др. На второй позиции находятся гипоарктические виды. Среди них, Betula nana L., Rubus arcticus L., Rubus chamaemorus, Cornus suecica. На значительных по площади поверхностях скал выступают характерные элементы северных и южных лишайниковых тундр, представители отдела Lichenomycota, а именно, Cladonia stellaris (Opiz) Pouzar \& Vězda, Cladonia sylvatica (L.) Hoffm., Cladonia rangiferina (L.) Weber ex F.H. Wigg., Cetraria islandica (L.) Ach., Peltigera aphthosa (L.) Willd.

Собранный гербарный материал (45 образцов 16-ти таксонов) передан автором Гербарию Национального лесотехнического университета Украины в 2018 году. Он в достаточной мере отображает наиболее характерные черты биоты скальных сосняков Кий-острова и является единственной коллекцией видов северной тайги европейской части России в Гербарии НЛТУ Украины, который официально за- 
регистрирован в международных базах данных под акронимом LWFU.

Ключевые слова: Кийский архипелаг; Белое море; скальные сосняки; бореальная и гипоарктическая флора; гербарные образцы.

\section{Plants and lichens from the Kiy Island in the Herbarium of the Ukrainian National Forestry University (LWFU)}

\section{T. Prykladivska ${ }^{1}$}

Kiy Island is an island at the Onega Bay of the White Sea, $8 \mathrm{~km}$ off shore, $15 \mathrm{~km}$ off the town Onega. Coordinates: $64^{\circ} 00^{\prime} \mathrm{N} ; 37^{\circ} 52^{\prime} \mathrm{E}$. The island is the massive of the granite rocks. Geomorphology and climate of island, especially proximity to Arctic Circle caused the peculiarity of its nature complexes. The greater part of the island territory is covered by Scotch pine forest.

The author visited the Kiy Island in July 1984 with aime to describe the forest biocenoses. As a result the composition of forest lichens, mosses, herbage and shrub age were described. Some forest associations were defined and predominance species were collected.

The most wide-spread forest associations of Kiy Island are: Pinetum cladinosum petraeum, MyrtillusCalluna-Cladina-Typ, Pinetum empetrosum petraeum, Cladino-Pinetum subass. polytrichetosum communis, Empetro-Cladino-Pinetum. They include the specific complex of species with wide ecological amplitude. Among them are the lichens of the dry location (Cladonia sp., Cetraria sp.) and the plants of swampy soil (Empetrum nigrum L., Ledum palustre L., Vaccinium uliginosum L., Andromeda polifolia L.).

Tetyana Prykladivska - PhD in Forestry, the 1-st category engineer in Department of plants reproduction of Botanical garden of Ukrainian National Forestry University, General Chuprynka st., 103, Lviv, 79057, Ukraine. Tel.: +38-032-237-88-20, E-mail: prikladivska_tet@i.ua ORCID:: 0000-0002-0265-0651
The more rare associations are: Pinetum uliginosivaccinioso-ledosum and Pinetum sphagnoso-ledosum. Their stands characterized by the lowest quality class, low density of canopy and high density of sward with such dominant plants as Ledum palustre, Vaccinium uliginosum, Vaccinium oxycoccos L., Eriophorum sp., Cornus suecica L., Rubus chamaemorus L., Polytrichum commune Hedw., Comarum palustre L.

The biggest part of all species is represented by the group of boreal plants: Andromeda polifolia, Arctostaphylos uva-ursi (L.) Spreng., Chamaedaphne calyculata (L.) Moench, Galium boreale L., Ledum palustre, Linnaea borealis L., Nardus stricta L. and others. The hypoarctic (arctic-boreal) plants such as Betula nana L., Rubus arcticus L., Rubus chamaemorus, Cornus suecica take the second place. The large group of collected species is represented by lichens: Cetraria islandica (L.) Ach., Cladonia stellaris (Opiz) Pouzar \& Vězda), Cladonia rangiferina (L.) Weber ex F.H. Wigg., Cladonia sylvatica (L.) Hoffm., Peltigera aphthosa (L.) Willd.

The analyses of species ranges distribution show the predominance $t$ of wide-ranges plants. First of all this is a group with the circumpolar ranges - Andromeda polifolia, Arctostaphylos uva-ursi, Calluna vulgaris L., Chamaedaphne calyculata, Ledum palustre, Linnea borealis, Vaccinium oxycoccos, Vaccinium myrtillus L., Vaccinium vitis-idaea L. and others. Also there are plants with amphiatlantic ranges (Betula nana, Rubus arcticus i Cornus suecica) and the Siberian elements of flora (Juniperus communis var. saxatilis Pall. and hybrid forms of Picea obovata Ledeb.). One of species is a rare plant: Cornus suecica includes in «Red Data Book of East Fennoscandia» (Status: 3 - Rare).

The collected herbarium was granted by the author to the UNFU in 2018. It includes 45 samples of 16 species lichens and plants. All of them are typical species from the north taiga and tundra zones. This northern herbal is one and only in the Herbarium of the Ukrainian National Forestry University (UNFU).

Key words: Kiy Archipelago; White Sea; Scotch pine rocks forest; boreal and hypoarctic flora; herbarium samples. 